\title{
Neuropharmacological Activities of Methanol Extract of Albizia lebbeck (L.) Benth.
}

\author{
Shanta Islam ${ }^{1}$, Md. Shafiullah Shajib ${ }^{1}$, Bidyut Kanti Datta ${ }^{1}$ and Mohammad A. Rashid ${ }^{2}$ \\ ${ }^{1}$ Department of Pharmacy, Stamford University Bangladesh, 51 Siddeswari Road, Dhaka-1217, Bangladesh \\ ${ }^{2}$ Department of Pharmaceutical Chemistry, Faculty of Pharmacy, University of Dhaka \\ Dhaka-1000, Bangladesh
}

(Received: 28 January, 2018; Accepted: 26 March, 2018; Published: 31 July, 2018)

\begin{abstract}
Albizia lebbeck (Linn.) Benth. is a deciduous tree which is planted as ornamental and avenue tree almost all over Bangladesh. Leaves of the plant are used in ethnomedicine for the treatment of convulsion and CNS related disorder. This study was aimed to evaluate the neuropharmacological effects of the methanol extract of A. lebbeck leaves in Swiss albino mice. The locomotor effect of crude methanol extract of the plant was investigated by open field and hole cross tests while the anxiolytic activity was determined using elevated plus-maze (EPM) and light/dark box (LDB) tests. Furthermore, the sedative activity of the plant extract was assessed by sodium thiopental-induced sleeping time test. The results demonstrated that the methanol extract significantly $(\mathrm{p}<0.001)$ reduced locomotion of the animals in both hole cross and open field tests in dose-dependent manner at 200-400 mg/kg b.w. In both EPM and LDB tests, the plant extract produced significant anxiolytic effect $(\mathrm{p}<0.05)$ at the doses of $100-400 \mathrm{mg} / \mathrm{kg}$ b.w. In addition, it showed significant $(\mathrm{p}<0.001)$ dose-dependent decrease in the onset of sleep and an increase in duration of sleep in sodium thiopental-induced sleeping time test. Preliminary phytochemical analyses of the plant extract revealed the presence of alkaloid, flavonoid, glycoside, saponin, tannin and resin. In acute toxicity test, the leaf extract did not exhibit any adverse effect in mice during 7 days treatment. The results of the present studies suggest that the crude methanol extract of A. lebbeck leaves possesses significant CNS depressant, anxiolytic and sedative properties and rationalize the traditional uses of the plant.
\end{abstract}

Key words: Albizia lebbeck, ethnomedicine, CNS depressant, anxiolytic, sedative.

\section{Introduction}

Albizia lebbeck (L) Benth. (Family: Mimosaceae) known locally as Shirish, is a fastgrowing medium-sized to large deciduous tree (approximately $12-21 \mathrm{~m}$ in height) with compound leaves, grayish-brown bark, reddish mimosaceous flowers, flat oblong fruits and flat, round, creamcoloured seeds (Vozzo, 2002; Ghani, 2003). The genus Albizia comprises about 150 species, which are found mostly throughout India, Bangladesh, tropical and sub-tropical regions of Asia and Africa. The tree is widely cultivated as an ornamental and plantation tree in almost all districts in Bangladesh (Ghani, 2003; Faisal et al., 2012).
It has been reported that the main bioactive constituents of A. lebbeck are alkaloids, flavonoids, tannins, triterpenes, glycosides, proteins, saponins and various sterols like taraxerol, cycloartemol, lupeol, campesterol, and $\beta$-sitosterol. Recently, two tri-o-glycoside flavonols, kaempferol and quercetin, and a hexaglycosylated saponin, albizziahexoside, have been isolated from the leaves of A. lebbeck (Yadav et al., 2011; Faisal et al., 2012). The leaves have been also found to contain non-protein amino acids and a large amount of keto acids including phosphoenol-pyruvate, glyoxylate, oxaloacetate and $\alpha$-oxoglutarate (Une et al., 2001). The leaf extract has been reported to exhibit antibacterial (Chulet et al.,

Correspondence to: Mohammad A. Rashid: Tel: 9661900-73, Extn. 8137, Fax: 880-2-966722; E-mail: rashidma@du.ac.bd 
2010), anticonvulsant (Kasture et al., 2000), diuretic (Sivakumar et al., 2013), immunomodulatory (Chaudhary et al., 2012), anti-asthmatic and nootropic (Faisal et al., 2012) activities.

A. lebbeck is extensively used in treatment of a wide range of diseases and disorders including asthma, arthritis, antiseptic, burns, boils, toothache, dysentery, allergic rhinitis, bronchitis, leprosy, leucoderma, ophthalmopathy, skin eruption, sprains, wounds, ulcers, paralysis and tuberculosis (Une et al., 2001; Zia-Ul-Haq et al., 2013). A decoction of leaves is also used for the central nervous system (CNS) depressant effect in folk medicine (Mathur, 2012). Therefore, considering the ethnomedicinal implications and previously reported bioactivities of A. lebbeck leaves, we have investigated neuropharmacological effects of methanol extract of the plant leaves. The plant extract was subjected for locomotor, anxiolytic and sedative activities in different animal models of CNS. Additionally, the acute toxicity of the crude plant extract was also estimated, and we here in, report the results of our preliminary findings.

\section{Materials and Methods}

Plant material and extraction: The leaves of $A$. lebbeck were collected from Sonargoan, Narrayangonj, Bangladesh in August 2013 and were identified by Sarder Nasir Uddin, Senior Scientific Officer, Bangladesh National Herbarium, Mirpur, Dhaka, Bangladesh. A voucher sample (DACB: 38500) has been deposited in the herbarium for further reference. The collected leaves were washed, dried in a mechanical dryer at $40{ }^{\circ} \mathrm{C}$ and ground to coarse powder. The powdered leaf (108 g) was soaked in $500 \mathrm{ml}$ of methanol. The mixture was occasionally stirred and kept at $25 \pm 2{ }^{\circ} \mathrm{C}$ for 10 days. Then the mixture was filtered through a cotton plug followed by Whatman filter paper no 1 and the filtrate was completely dried using a rotary evaporator at $40^{\circ} \mathrm{C}$ and 50 r.p.m. under reduced pressure. Finally, $14.78 \mathrm{~g}$ extract (yield $13.69 \%$ ) was obtained which was further used for the phytochemical and pharmacological studies.
Preliminary phytochemical screening: The crude methanol extract of A. lebbeck leaves was qualitatively analyzed to detect the presence of carbohydrates, glycosides, cardiac glycosides, saponins, flavonoids, tannins, steroids, coumarins, resins, and alkaloids, following the procedures as previously described by Ghani (2005).

Experimental animals: Swiss Albino mice of 8 10 weeks aged, weighing between 25 - 30 gm, were collected from the Animal Resources Branch of the International Center for Diarrhoeal Disease and Research, Bangladesh (icddr,b). They were given icddr,b formulated food and fresh water ad libitum. The animals were acclimatized to the laboratory environment for 14 days prior to the experiments and were maintained under standard environmental conditions (temperature: $25.0 \pm 2.0^{\circ} \mathrm{C}$; relative humidity: 55 - $60 \%$ and $12 \mathrm{hrs}$ light/12 hrs dark cycle). All the experimental animals were treated following the Ethical Principles and Guidelines for Scientific Experiments on Animals (1995) drafted described by the Swiss Academy of Medical Sciences and Swiss Academy of Sciences. All the protocols were approved by the Institutional Ethics Committee of Stamford University Bangladesh (SUB/IAEC/ 13.09).

Drugs and treatments: Standard drugs used in this study were diazepam (Square Pharmaceutical Ltd., Bangladesh) and sodium thiopental (Gonoshastho Pharmaceuticals Ltd., Bangladesh). The vehicle ( $0.9 \%$ saline water; $10 \mathrm{ml} / \mathrm{kg}$ b.w., p.o.), methanol extract of $A$. lebbeck leaves (100, 200 and $400 \mathrm{mg} / \mathrm{kg}$ b.w., p.o.), diazepam (1 mg/kg b.w., i.p.) and sodium thiopental (40 mg/kg b.w., i.p.) were administered $30 \mathrm{~min}$ before the experiments started.

Acute toxicity test: The oral acute toxicity test of the plant extract was observed in four test groups ( $\mathrm{n}=$ 5) at the dose of 500,1000, 2000 and $3000 \mathrm{mg} / \mathrm{kg}$ b.w. After gavaging, the mice were kept in separate cages and allowed for free access of water ad libitum and food. Each animal was observed for mortality, allergic reactions, and any abnormal behaviors continuously for the first $4 \mathrm{~h}$ and next 7 days after treatment (Shang et al., 2015). 


\section{Locomotor activity}

Open field test: This experiment was carried out on apparatus, measuring $50 \times 50 \times 50 \mathrm{~cm}^{3}$ in size. The floor of the open field was divided into series of squares and each square painted in black and white in an alternative format. Thirty minutes after the treatment with diazepam (1 $\mathrm{mg} / \mathrm{kg}$, i.p. $)$ and experimental groups, mice were individually placed in the center area of the open field and then the number of squares traveled was counted for $3 \mathrm{~min}$ at 0, 30, 60, 90 and $120 \mathrm{~min}$ during the observation period (Gupta et al., 1971). The percent inhibition was calculated as: \% Inhibition $=[\{$ Mean squares travel (Control) - Mean squares travel (Treatment) $\} /\{$ Mean squares travel $($ Control) $\}] \times 100$.

Hole cross test: The hole cross test was performed according to the method described by Takagi et al., (1971). The apparatus was $30 \mathrm{~cm} \times 20$ $\mathrm{cm} \times 14 \mathrm{~cm}^{3}$ in size and provided with a fixed partition in the middle of the cage. A hole of $3 \mathrm{~cm}$ in diameter was made in the partition to move the mice freely from one chamber to other. Each animal was placed beside the wall of one chamber facing to the hole thirty minutes after the treatment with standard and experimental groups. Then the number of hole crossed was counted for 3 min at $0,30,60,90$ and $120 \mathrm{~min}$ during the observation period and the percent inhibition of number of hole crossed was calculated.

\section{Anxiolytic activity}

Elevated plus-maze test: The apparatus consisted of two opposite open arms, two opposite enclosed arms and a central platform measuring of $(50 \times 10$ $\mathrm{cm}),(50 \times 10 \times 40 \mathrm{~cm})$ and $(5 \mathrm{~cm} \times 5 \mathrm{~cm})$, respectively. Each type of arms was arranged like plus sign and was elevated to a height of $50 \mathrm{~cm}$ from the ground level. Then, $30 \mathrm{~min}$ before the experiment, mice were individually placed in the center of the apparatus facing one of the open arms. The number of entries and time spent on the open and enclosed arms was observed during a period of $5 \mathrm{~min}$ (Pellow et al., 1985). An arm entry was counted when all four paws were in the arm. The percentage of open arm entries and the time spent in open arm were measured using the following formula:

$\%$ of open arms time spent $=$ [open arms time/(open arms time + closed arms time) $] \times 100$

$\%$ of open arms entries $=[$ open arms entries/(open arms entries + closed arms entries)] $\times 100$

Light/dark box test: The experiment was carried out as the procedure described by Hascoet and Bourin (1998). The light/dark box apparatus was consisted of a rectangular wooden box $(46 \times 27 \times 30$ $\mathrm{cm})$ and was divided into the typical dimensions of one-third for the dark compartment and two-thirds for the light compartment. To move freely from one part of the chamber to other both sections were connected by an opening of $7.5 \times 7.5 \mathrm{~cm}$ at floor level. The light compartment was brightly illuminated with a light source of 400 lux which placed $35 \mathrm{~cm}$ above the box. 30 minutes after treatment with the vehicle, methanol extract or diazepam, each mouse was individually placed in the corner of the light compartment, facing away from the entry to the dark compartment. The mice were monitored for a period of $5 \mathrm{~min}$ and the following parameters were observed and quantified: (a) latency of the first crossing from one compartment to the other, (b) time spent into light and dark compartment, (c) the number of transition between the light and dark compartment.

\section{Sedative activity}

Sodium thiopental-induced sleeping time determination: The experiment was conducted as previously described by Ferrini et al., (1974). Mice were injected with sodium thiopental $(40 \mathrm{mg} / \mathrm{kg}$ b.w.), $30 \mathrm{~min}$ after the vehicle, methanol extract of plant leaves or diazepam treatment to induce sleep. Immediately after administration of sodium thiopental, the animals were observed for the latent period (time between sodium thiopental injections to loss of righting reflex). The duration of sleep was recorded from the time of loss to the recovery of the righting reflex. 


\section{Statistical analysis}

The results were expressed as a mean \pm standard error of the mean (SEM). The statistical analysis was performed using one-way analysis of variance (ANOVA) followed by Dunnett's or Bonferroni's post hoc test using SPSS 22.00 software.

\section{Results and Discussion}

In the present study, we evaluated the neuropharmacological effects of the methanol extract of A. lebbeck leaves in mice. Our results demonstrated that the oral administration of methanol extract of plant leaf elicit potent and dose-dependent CNS depressant, anxiolytic and sedative activities. Moreover, there were no death, allergic reaction or any behavioral changes observed at the doses of 500 - $3000 \mathrm{mg} / \mathrm{kg}$ b.w. in any animals during 7 days observation period, which can be suggested that the plant extract possesses a low toxicity profile.

Open field and hole cross tests are most widely used methods to investigate the locomotor activity of the animals. Locomotor activity refers to an index of alertness and a decrease in that indicates a sedative effect (Thakur and Mengi, 2005). Our results demonstrated that the leaf extract significantly ( $\mathrm{p}<$ 0.001 ) reduced locomotion of the animals in both hole cross and open field tests. The number of squares traveled by the mice in open field test was suppressed significantly from its initial score by the treatment of the extract which was comparable to the reference drug diazepam. The dose $(400 \mathrm{mg} / \mathrm{kg} \mathrm{b.w.)}$ of the methanol extract exhibited maximum inhibition by $54.55 \%$ at $120 \mathrm{~min}$ which was closer to the standard drug, diazepam (59.90\%) (Table 1). The extract at 200 and $400 \mathrm{mg} / \mathrm{kg}$ b.w. also produced significant $(p<0.001)$ decrease of movement in hole cross experiment. The highest inhibition of the hole cross movement was demonstrated by the extract at $400 \mathrm{mg} / \mathrm{kg}$ b.w. by $76.74 \%$ at $90 \mathrm{~min}$ where diazepam showed a maximum of the inhibition by $87.18 \%$ at $120 \mathrm{~min}$ (Table 2).

Table 1. Effect of methanol extract of leaf of A. lebbeck during open field test in mice model.

\begin{tabular}{lcccccc}
\hline Treatment & $\begin{array}{c}\text { Dose } \\
(\mathrm{mg} / \mathrm{kg})\end{array}$ & \multicolumn{5}{c}{ Number of square crossed (\% inhibition) } \\
\cline { 3 - 6 } & & $0 \mathrm{~min}$ & $30 \mathrm{~min}$ & $60 \mathrm{~min}$ & $90 \mathrm{~min}$ & $120 \mathrm{~min}$ \\
\hline Vehicle & - & $84.80 \pm 2.46$ & $66.60 \pm 3.28$ & $49.80 \pm 3.17$ & $41.80 \pm 3.89$ & $38.40 \pm 2.75$ \\
Diazepam & 1 & $87.60 \pm 2.54$ & $36.80 \pm 2.11^{*}$ & $24.40 \pm 1.82^{*}$ & $17.60 \pm 0.92^{*}$ & $15.40 \pm 0.61^{*}$ \\
& & $(-3.30)$ & $(44.74)$ & $(51.00)$ & $(57.89)$ & $(59.90)$ \\
MEAL & 100 & $85.20 \pm 4.34$ & $49.8 \pm 2.63$ & $33.40 \pm 2.24^{*}$ & $28.20 \pm 1.63$ & $27.60 \pm 0.73$ \\
& & $(-0.47)$ & $(25.23)$ & $(32.93)$ & $(32.54)$ & $(28.13)$ \\
MEAL & 200 & $86.40 \pm 4.04$ & $45.20 \pm 1.78^{*}$ & $29.40 \pm 2.20^{*}$ & $25.60 \pm 1.66^{*}$ & $24.40 \pm 2.48^{*}$ \\
& & $(-1.89)$ & $(32.13)$ & $(40.96)$ & $(38.76)$ & $(36.46)$ \\
MEAL & 400 & $86.80 \pm 3.10$ & $39.40 \pm 2.55^{*}$ & $25.40 \pm 1.85^{*}$ & $19.00 \pm 1.41^{*}$ & $17.20 \pm 1.07^{*}$ \\
& & $(-2.36)$ & $(40.84)$ & $(49.00)$ & $(54.55)$ & $(55.21)$ \\
\hline
\end{tabular}

Each value is presented as mean \pm SEM $(\mathrm{n}=5)$. MEAL $=$ methanol extract of $A$. lebbeck leaves. * $p<0.001$, compared with the control group (Dunnett's test).

The elevated plus maze (EPM) and light/dark box (LDB) test are commonly used behavioral models and have been validated to investigate both the anxiolytic and anxiogenic potential of different pharmacological agents. They both utilize the animals via naturally occurring anxiety-related activities such as fear of novel environments including light, open space, height and fear of balancing on the narrow surface (Hascoet and Bourin, 1998; Dawson and Tricklebank, 1995). Results of the EPM test showed that the treatment of the plant methanol extract at 200 and $400 \mathrm{mg} / \mathrm{kg}$ b.w. 
produced significant $(\mathrm{p}<0.001)$ increase in time spent on open arms and decrease in time spent in enclosed arms. Besides, the percent open arm entries of the extract treated mice were also significant ( $\mathrm{p}<$ 0.001) (Table 3). In the LDB test, the methanol extract treatment of mice on latency time, time spent and transition in light area, were significant $(\mathrm{p}<$ 0.05) compared to the control group as shown in table 4. The maximum percent inhibition was observed at the dose of $400 \mathrm{mg} / \mathrm{kg}$ in both tests (Tables 3 and 4).

Table 2. Effect of methanol extract of leaf of $A$. lebbeck during hole cross test in mice model.

\begin{tabular}{|c|c|c|c|c|c|c|}
\hline \multirow[t]{2}{*}{ Treatment } & \multirow{2}{*}{$\begin{array}{c}\text { Dose } \\
(\mathrm{mg} / \mathrm{kg})\end{array}$} & \multicolumn{5}{|c|}{ Number of hole crossed (\% inhibition) } \\
\hline & & $0 \mathrm{~min}$ & $30 \mathrm{~min}$ & $60 \mathrm{~min}$ & $90 \mathrm{~min}$ & $120 \mathrm{~min}$ \\
\hline Vehicle & - & $13.00 \pm 0.49$ & $11.20 \pm 0.77$ & $9.40 \pm 0.83$ & $8.60 \pm 0.61$ & $7.80 \pm 0.59$ \\
\hline Diazepam & 1 & $\begin{array}{c}12.60 \pm 0.73 \\
(3.08)\end{array}$ & $\begin{array}{c}5.20 \pm 0.33^{*} \\
\quad(53.57)\end{array}$ & $\begin{array}{c}2.60 \pm 0.67 * \\
(72.34)\end{array}$ & $\begin{array}{c}1.60 \pm 0.22 * \\
(81.40)\end{array}$ & $\begin{array}{c}1.00 \pm 0.28^{*} \\
(87.18)\end{array}$ \\
\hline MEAL & 100 & $\begin{array}{c}13.40 \pm 0.96 \\
(-3.08)\end{array}$ & $\begin{array}{c}9.40 \pm 0.61 \\
\quad(16.07)\end{array}$ & $\begin{array}{c}6.60 \pm 0.46 \\
(29.79)\end{array}$ & $\begin{array}{c}5.00 \pm 0.49^{*} \\
(41.86)\end{array}$ & $\begin{array}{c}4.40 \pm 0.61 * \\
(43.59)\end{array}$ \\
\hline MEAL & 200 & $\begin{array}{c}12.80 \pm 0.66 \\
(1.54)\end{array}$ & $\begin{array}{c}7.80 \pm 0.59 \\
(30.36)\end{array}$ & $\begin{array}{c}4.60 \pm 0.61 * \\
(51.06)\end{array}$ & $\begin{array}{c}3.60 \pm 0.46^{*} \\
(58.14)\end{array}$ & $\begin{array}{c}3.20 \pm 0.44^{*} \\
(58.97)\end{array}$ \\
\hline MEAL & 400 & $\begin{array}{c}13.20 \pm 0.77 \\
(-1.54)\end{array}$ & $\begin{array}{c}6.40 \pm 0.46^{*} \\
(42.86)\end{array}$ & $\begin{array}{c}3.40 \pm 0.22^{*} \\
(63.83)\end{array}$ & $\begin{array}{c}2.00 \pm 0.28^{*} \\
\quad(76.74)\end{array}$ & $\begin{array}{c}2.20 \pm 0.33^{*} \\
(71.79)\end{array}$ \\
\hline
\end{tabular}

Each value is presented as mean \pm SEM $(n=5)$. MEAL $=$ methanol extract of $A$. lebbeck leaves. * $p<0.001$, compared with the control group (Dunnett's test).

Table 3. Effect of methanol extract of leaf of $A$. lebbeck during elevated plus-maze test in mice model.

\begin{tabular}{llllllll}
\hline Treatment & $\begin{array}{c}\text { Dose } \\
(\mathrm{mg} / \mathrm{kg})\end{array}$ & $\begin{array}{l}\text { Enclosed arms } \\
\text { time }(\mathrm{sec})\end{array}$ & $\begin{array}{l}\text { Open arms } \\
\text { time }(\mathrm{sec})\end{array}$ & $\begin{array}{l}\text { \% of open } \\
\text { arm time } \\
(\mathrm{sec})\end{array}$ & $\begin{array}{l}\text { Enclosed } \\
\text { arms entries }\end{array}$ & $\begin{array}{l}\text { Open arms } \\
\text { entries }\end{array}$ & $\begin{array}{l}\% \text { of open } \\
\text { arm entries }\end{array}$ \\
\hline Vehicle & - & $271.55 \pm 4.27$ & $28.45 \pm 4.27$ & $9.48 \pm 1.42$ & $16.60 \pm 1.22$ & $4.80 \pm 0.66$ & $22.57 \pm 3.10$ \\
Diazepam & 1 & $146.34 \pm 6.55^{*}$ & $153.66 \pm 6.55^{*}$ & $51.22 \pm 2.18$ & $3.60 \pm 0.46$ & $8.20 \pm 0.66^{*}$ & $69.77 \pm 3.01$ \\
MEAL & 100 & $211.05 \pm 5.92^{*}$ & $88.95 \pm 5.92^{*}$ & $29.65 \pm 1.97$ & $12.60 \pm 1.97$ & $5.60 \pm 0.96$ & $32.73 \pm 7.32$ \\
MEAL & 200 & $176.20 \pm 6.70^{*}$ & $123.80 \pm 6.70^{*}$ & $41.27 \pm 2.23$ & $7.60 \pm 1.40$ & $7.40 \pm 0.54$ & $51.77 \pm 6.99$ \\
MEAL & 400 & $160.98 \pm 6.37^{*}$ & $139.02 \pm 6.37^{*}$ & $46.34 \pm 2.12$ & $5.20 \pm 0.87$ & $8.00 \pm 1.02^{*}$ & $60.79 \pm 6.56$ \\
\hline
\end{tabular}

Each value is presented as mean \pm SEM $(\mathrm{n}=5)$. MEAL $=$ methanol extract of A. lebbeck leaves $* p<0.001$, compared with the control group (Dunnett's test).

Table 4. Effect of methanol extract of leaf of A. lebbeck during light/dark box test in mice model.

\begin{tabular}{lccccccc}
\hline Treatment & $\begin{array}{c}\text { Dose } \\
(\mathrm{mg} / \mathrm{kg})\end{array}$ & $\begin{array}{c}\text { Latency } \\
\text { time }(\mathrm{s})\end{array}$ & $\begin{array}{c}\text { Time spent in } \\
\text { light area }(\mathrm{s})\end{array}$ & $\begin{array}{c}\text { \% of light } \\
\text { area time }(\mathrm{s})\end{array}$ & $\begin{array}{c}\text { Transition in } \\
\text { light area }\end{array}$ & $\begin{array}{c}\text { \% of light } \\
\text { area entries }\end{array}$ & $\begin{array}{c}\text { Total transition } \\
\text { no. }\end{array}$ \\
\hline Vehicle & - & $11.18 \pm 1.40$ & $86.71 \pm 4.62$ & $28.90 \pm 1.54$ & $4.60 \pm 0.61$ & $25.97 \pm 4.39$ & $18.40 \pm 0.96$ \\
Diazepam & 1 & $32.08 \pm 1.50^{*}$ & $177.26 \pm 7.52^{*}$ & $59.09 \pm 2.51$ & $7.00 \pm 0.63^{* *}$ & $65.79 \pm 6.53$ & $10.80 \pm 0.56^{*}$ \\
MEAL & 100 & $16.54 \pm 1.22$ & $117.87 \pm 6.08^{* *}$ & $39.29 \pm 2.03$ & $5.80 \pm 0.52$ & $39.13 \pm 3.38$ & $14.80 \pm 0.33^{* *}$ \\
MEAL & 200 & $22.60 \pm 1.67^{*}$ & $133.83 \pm 5.36^{*}$ & $44.30 \pm 1.71$ & $6.20 \pm 0.52$ & $50.71 \pm 6.89$ & $12.60 \pm 0.67^{*}$ \\
MEAL & 400 & $29.36 \pm 1.03^{*}$ & $157.17 \pm 5.05^{*}$ & $52.39 \pm 1.68$ & $6.80 \pm 0.33$ & $67.58 \pm 4.34$ & $10.20 \pm 0.59^{*}$ \\
\hline
\end{tabular}

Each value is presented as mean $\pm \operatorname{SEM}(\mathrm{n}=5)$. MEAL $=$ methanol extract of A. lebbeck leaves. $* p<0.001, * * p<0.05$, compared with the control group (Dunnett's Test). 
Table 5. Effect of methanol extract of leaf of A. lebbeck druing sodium thiopental-induced sleeping test in mice model.

\begin{tabular}{llll}
\hline Treatment & Dose $(\mathrm{mg} / \mathrm{kg})$ & $\begin{array}{l}\text { Onset of Sleep } \\
(\mathrm{sec})\end{array}$ & $\begin{array}{l}\text { Duration of Sleep } \\
(\mathrm{min})\end{array}$ \\
\hline Vehicle + ST & $0.1 \mathrm{~mL} /$ Mouse +40 & $175.00 \pm 2.51$ & $32.61 \pm 1.05$ \\
Diazepam + ST & $1+40$ & $94.84 \pm 4.49^{*}$ & $93.30 \pm 1.41^{*}$ \\
MEAL + ST & $100+40$ & $154.67 \pm 2.63$ & $45.68 \pm 1.64$ \\
MEAL + ST & $200+40$ & $123.66 \pm 3.34^{*}$ & $67.65 \pm 1.76^{*}$ \\
MEAL + ST & $400+40$ & $91.99 \pm 2.58^{*}$ & $79.07 \pm 3.85^{*}$ \\
\hline
\end{tabular}

Each value is presented as the mean \pm SEM $(n=5), M E A L=$ methanol extract of $A$. lebbeck leaves, $\mathrm{ST}=$ sodium thiopental . *p $<0.001$, compared with the control group (Dunnett's test).

The sedative activity was evaluated by the sodium thiopental-induced sleeping test. Sedativehypnotic agent, thiopental, which belongs to the barbiturates, at appropriate doses produced sedation or hypnosis by potentiating GABA mediated hyperpolarization of postsynaptic inhibition through allosteric modification of $\mathrm{GABA}_{\mathrm{A}}$ receptors. These results in CNS depressant effect by the means of decreasing sleep latency or prolonging the duration of sleep or both (Sieghart and Sperk, 2002). In our study, the A. lebbeck leaves extract treatment showed significant $(p<0.001)$ dose-dependent decrease in the onset of sleep and an increase in duration of sleep (Table 5). So, it could be suggested that the leaves of the plant possess sleep-inducing property.

The phytochemical analyses of the crude methanol leaf extract of $A$. lebbeck revealed the presence of alkaloid, flavonoid, glycoside, cardiac glycoside, saponin, tannin, and resin. Moreover, A. lebbeck leaves have also been reported to have kaempferol, quercetin favanoids and albizziahexoside saponin (Yadav et al., 2011; Faisal et al., 2012). It has been reported that quercetin and kaempferol possess anxiolytic and sedative activities (AguirreHernández et al., 2010; Jäger and Saaby, 2011). Saponins are also found to exhibit sedative activity (Wagner et al., 1983). Considering our results and previously published reports, it can be suggested that the anxiolytic and sedative activities observed for the plant extract might be due to the presence of CNS active compounds.
In summary, the neuropharmacological study has shown that the methanol extracts of A. lebbeck leaves have central nervous system related effects. In hole cross and open field tests, suppression of locomotor activity was dose-dependent and significant. The plant extract also demonstrated a significant anxiolytic activity. In sodium thiopental-induced sleeping time test, the methanol extract of A. lebbeck showed significant dose-dependent effect in the sleep latency and duration of sleep. Based on the results of the present study, it could be concluded that the plant extracts possess remarkable CNS depressant, anxiolytic and sedative potential. Therefore, further studies regarding isolation and determination of the bioactivity of isolated compounds from the plants would be worthful for the development of CNS active agents.

\section{References}

Aguirre-Hernández, E., González-Trujano, M.E., Martínez, A.L., Moreno, J., Kite, G., Terrazas, T. and SotoHernández, M. 2010. HPLC/MS analysis and anxiolytic-like effect of quercetin and kaempferol flavonoids from Tilia americana var. mexicana. $J$. Ethnopharmacol. 127, 91-97.

Chaudhary, M., Sharma, A.K., Kumar, R., Chauhan, B., Kaushik, K. and Agarwal, V. 2012. Comparative immunomodulator activity of leaves and bark of Albizia lebbeck (Linn.) benth. Int. J. Res. Dev. Pharm. L. Sci. 1, 25-27.

Chulet, R., Pradhan, P., Sarwan, S.K. and Mahesh, J.K. 2010. Phytochemical screening and antimicrobial activity of Albizzia lebbeck. J. Chem. Pharm. Res. 2, 476-484. 
Dawson, G.R. and Tricklebank, M.D. 1995. Use of the elevated plus maze in the search for novel anxiolytic agents. Trends Pharmacol. Sci. 16, 33-36.

Faisal, M., Singh, P.P. and Irchhaiya, R. 2012. Review on Albizia lebbeck a potent herbal drug. Int. Res. J. Pharm. 3, 63-68.

Ferrini, R., Miragoli, G. and Taccardi, B. 1974. Neuropharmacological studies on SB 5833, a new psychotherapeutic agent of the benzodiazepine class. Arzneimittelforschung 24, 2029.

Ghani, A. 2003. Medicinal Plants of Bangladesh: Chemical Constituents and Uses, Asiatic Society of Bangladesh.

Ghani, A. 2005. Practical Phytochemistry Dhaka: Parash Publishers, Dhaka.

Gupta, B.D., Dandiya, P.C. and Gupta, M.L. 1971. A psycho-pharmacological analysis of behaviour in rats. Jpn. J. Pharmacol. 21, 293-298.

Hascoët M. and Bourin M. 1998. A new approach to the light/dark test procedure in mice. Pharmacol. Biochem. Behav. 60, 645-53.

Jäger, A.K. and Saaby, L. 2011. Flavonoids and the CNS. Molecules. 16, 1471-1485.

Kasture, V.S., Chopde, C.T. and Deshmukh, V.K. 2000. Anticonvulsive activity of Albizzia lebbeck, Hibiscus rosa sinesis and Butea monosperma in experimental animals. J. Ethnopharmacol. 71, 65-75.

Mathur, M. 2012. Use of quantitative ethnobotany for assessing potential and conservation priorities of the Indian Thar desert medicinal plants claimed for central nervous disorders. Med. Plants. Int. J. Phytomed. Related Industr. 4, 143-153.

Pellow, S., Chopin, P., File, S.E. and Briley, M. 1985. Validation of open: closed arm entries in an elevated plus-maze as a measure of anxiety in the rat. $J$. Neurosci. Methods. 14, 149-167.
Shang, X., Wang, D., Miao, X., Wang, Y., Zhang, J., Wang, X., Zhang, Y. and Pan, H. 2015. Antinociceptive and anti-tussive activities of the ethanol extract of the flowers of Meconopsis punicea Maxim. BMC Complement. Altern. Med. 15, 154.

Sieghart, W. and Sperk, G. 2002. Subunit composition, distribution and function of $\mathrm{GABA}_{\mathrm{A}}$ receptor subtypes. Curr. Top. Med. Chem. 2, 795-816.

Sivakumar, B., Velmurugan, C. and Kumar, P.L. 2013. Diuretic activity of methanolic extract of Albizia lebbeck. Int. J. Pharmtech Res. 5, 404-406.

Takagi, K., Watanabe, M. and Saito, H. 1971. Studies of the spontaneous movement of animals by the hole cross test; effect of 2-dimethyl-aminoethanol and its acyl esters on the central nervous system. Jpn. J. Pharmacol. 21, 797-810.

Thakur, V.D. and Mengi, S.A. 2005. Neuropharmacological profile of Eclipta alba (Linn.) Hassk. J. Ethnopharmacol. 102, 23-31.

Une, H.D., Pal, S.C., Kasture, V.S. and Kasture, S.B. 2001. Phytochemical constituents and pharmaco-logical profile of Albizzia lebbeck. J. Nat. Remedies. 1, 1-5.

Vozzo, J.A. 2002. Tropical Tree Seed Manual. Agriculture Hankbook 721, USDA Forest Service, Washignton DC.

Wagner, H., Ott, S., Jurcic, K., Morton, J. and Neszmelyi, A. 1983. Chemistry, 13C-NMR study and pharmacology of two saponins from Colubrina asiatica. Planta Med. 48, 136-141.

Yadav, S.S., Galib, Prajapati, P.K. and Harisha, C.R. 2011. Pharmacognostical and physico-chemical investigations of Albizia lebbeck benth. flower. Int. J. Pharm. Biol. Arch. 2, 1434-1438.

Zia-Ul-Haq, M., Ahmad, S., Qayum, M. and Ercişli, S. 2013. Compositional studies and antioxidant potential of Albizia lebbeck (L.) Benth. pods and seeds. Turk. J. Biol. 37, 25-32. 